\title{
PLANTAR FOOTPRINTS ANALYSIS - CASE STUDY (PART 1)
}

\section{ANALIZA AMPRENTELOR PLANTARE - STUDIU DE CAZ (PARTEA 1)}

\author{
Aura MIHAI $^{1}$, Guillaume HORTAL ${ }^{2}$, Mariana $\operatorname{COSTEA}^{1 *}$ \\ ${ }^{1}$ Faculty of Textile, Leather and Industrial Management, "Gheorghe Asachi" Technical University of lasi, 53 Dimitrie Mangeron Blvd., 700050, \\ lasi, Romania, e-mail: mariana.pastina@yahoo.com
}

${ }^{2}$ Student, National School of Arts and Textile Industries of Roubaix, France

PLANTAR FOOTPRINTS ANALYSIS - CASE STUDY (PART 1)

ABSTRACT. This study aims to analyze the plantar footprints based on biomechanical parameters obtained through plantar pressure measurements and to present an easy to use methodology for establishing the foot type in order to further suggest orthopaedic devices, such as customized soles and insoles. Using the RSScan pressure plate and the Footscan software, fine observations both on foot and on repartition of foot pressures are made. By analyzing the maximum pressures obtained in this case study, the highest values were registered under $3^{\text {rd }}$ and $4^{\text {th }}$ metatarsal bones, suggesting that the investigated subject has different arrangements of high pressures compared with the ones reported by other similar studies. The gait time has been analysed, resulting in a normal distribution of this parameter on each area of the foot. By comparing the results, the left foot has been demonstrated to be high arched.

KEY WORDS: plantar pressure, gait, foot, footprint

ANALIZA AMPRENTELOR PLANTARE - STUDIU DE CAZ (PARTEA 1)

REZUMAT. Acest studiu îşi propune să analizeze amprentele plantare pe baza parametrilor biomecanici obţinuţi prin măsurătorile presiunilor plantare şi să elaboreze o metodologie uşor de urmat pentru stabilirea tipologiei piciorului, în vederea sugerării dispozitivelor ortopedice, cum ar fi tălpile şi branţurile personalizate. Folosind placa de presiune RSScan şi software-ul Footscan sunt observate repartiţiile presiunilor la nivelul picioarelor. Prin analiza presiunilor maxime obţinute în acest studiu de caz, se poate observa că cele mai mari valori au fost înregistrate sub oasele metatarsiene 3 şi 4 , sugerând astfel faptul că subiectul investigat are zone de presiune ridicată diferite, comparativ cu cele raportate de alte studii similare. A fost analizat timpul corespunzător efectuării unui pas, rezultând o distribuţie normală a acestui parametru pe fiecare zonă a piciorului. Prin compararea rezultatelor, s-a demonstrat că piciorul stâng este de tip picior scobit.

CUVINTE CHEIE: presiuni plantare, mers, picior, amprentă

\section{L'ANALYSE D'EMPREINTES PLANTAIRES - ÉTUDE DE CAS (PREMIÈRE PARTIE)}

RÉSUMÉ. Cette étude a le but d'analyser les empreintes plantaires à partir des paramètres biomécaniques obtenues par des mesures de pression plantaire et de développer une méthodologie facile à suivre pour établir la typologie du pied, en vue de recommander des dispositifs orthopédiques tels que les semelles et les premières personnalisées. En utilisant la plateforme de pression RSScan et le logiciel Footscan, on a observé les distributions de pression dans les pieds. En analysant la pression maximale atteinte dans cette étude de cas, on constate que les valeurs les plus élevées ont été enregistrées dans les métatarses 3 et 4 , ce qui suggère que le sujet étudié a régions de haute pression différentes de celles rapportées par des études similaires. On a analysé le temps nécessaire pour faire un pas, résultant en une distribution normale de ce paramètre sur chaque région du pied. En comparant les résultats, on a montré que le pied gauche est un type de pied creux.

MOTS CLÉS: pressions plantaires, démarche, pied, empreinte

\section{INTRODUCTION}

Feet are certainly the most stressed part of the body. Walking, running or just keeping the balance with one or both feet on the ground are daily, ordinary activities. Feet are often affected by problems which could be the preliminary source for various wounds and pains in the entire body.

Plantar pressure measurements have been widely used for studying foot and/or body biomechanics.

\section{INTRODUCERE}

Picioarele sunt cu siguranţă partea cea mai solicitată a corpului. Mersul pe jos, alergatul sau păstrarea echilibrului cu unul sau cu ambele picioare pe suprafaţa de sprijin sunt activităţi obişnuite, de zi cu zi. Picioarele sunt adesea afectate de probleme, aceasta putând fi sursa apariţiei diferitelor răni şi dureri în tot corpul.

Măsurătorile presiunilor plantare au fost utilizate la scară largă pentru a studia biomecanica picioarelor

* Correspondence to: Mariana COSTEA, Faculty of Textile, Leather and Industrial Management, "Gheorghe Asachi" Technical University of lasi, 53 Dimitrie Mangeron Blvd., 700050, lasi, Romania, e-mail: mariana.pastina@yahoo.com 
Previous studies have shown that measuring plantar pressures has valuable practical applications, in order to reveal current or upcoming feet problems or disorders [1-3]. Common measuring methods are based on specialized equipment such as pressure plates or pressure insoles [4]. Plantar pressure data varies from one subject to another, and they should be analyzed based on some hypotheses related to a normal gait pattern. Even when we are talking about a normal gait pattern, the results of plantar pressure measurements are influenced by various factors which are difficult to identify. Most of the studies report the results of one single parameter. Thus, matching up the results from different studies is becoming more and more complex [5].

\section{METHOD}

This study aims to analyze the plantar footprints and to present a methodology for a quick view of the foot type in order to further suggest orthopaedic devices, such as customized soles or insoles.

The subject selected for this case study is a 24year-old male, $1.68 \mathrm{~m}$ tall and weighing $60 \mathrm{~kg}$. The subject is free of foot pain and had not previously had serious injuries or medical treatments associated to lower limb. Also, he did not report difficulties interfering with walking or with other daily activities.

The RSScan 2D plate of $0.5 \mathrm{~m}$ and its associated software, namely Footscan Gait Scientific, have been used. The experimental task followed comprises measurements in:

- statics - the subject was required to find his balance on the pressure plate having his weight equally distributed on both feet. Then a capture of its plantar pressure was taken.

- dynamics - the subject was required to walk, stepping on pressure plate with the left foot. One capture in dynamics was taken. The subject repeated this movement stepping with the right foot on the plate. Five measurements on each foot were taken in order to obtain reliable and comparable sets of data.

According to Naemi [6], a three-meter walkway is recommended for a complete gait analysis. Thus, the şi/sau a corpului. Studiile anterioare au arătat că măsurarea presiunilor plantare are aplicaţii practice valoroase, în scopul descoperirii problemelor sau afecţiunilor picioarelor [1-3]. Metodele de măsurare obişnuite au la bază echipamente specializate, precum plăci de presiune sau branţuri de presiune [4]. Datele presiunii plantare variază de la un subiect la altul şi ar trebui să fie analizate pe baza unor ipoteze legate de un model normal de mers. Chiar şi atunci când vorbim despre un model de mers normal, rezultatele măsurătorilor presiunii plantare sunt influenţate de diverşi factori şi se pot ivi dificultăţi. Majoritatea studiilor raportează rezultatele unui singur parametru. Astfel, compararea rezultatelor între diferite studii devine din ce în ce mai complexă [5].

\section{METODĂ}

Acest studiu îşi propune să analizeze amprentele plantare şi să prezinte o metodologie pentru vizualizarea rapidă a tipologiei piciorului, în scopul sugerării dispozitivelor ortopedice, cum ar fi tălpi sau branţuri personalizate.

Subiectul selectat pentru acest studiu de caz este un bărbat cu vârsta de 24 ani, având înălţimea de 1,68 $\mathrm{m}$ şi greutatea de $60 \mathrm{~kg}$. Subiectul nu prezintă dureri la nivelul picioarelor şi nu a avut leziuni grave sau tratamente medicale asociate cu membrele inferioare. De asemenea, el nu a raportat probleme care să-i afecteze mersul sau alte activităţi de zi cu zi.

$\mathrm{Au}$ fost utilizate pentru acest studiu placa 2D RSScan de lungime $0,5 \mathrm{~m}$ şi software-ul asociat, Footscan Gait Scientific. Secvenţa experimentală urmată cuprinde măsurători în:

- statică - subiectul s-a poziţionat în echilibru pe placa de presiune, având greutatea distribuită în mod egal pe ambele picioare. Apoi a fost preluată presiunea plantară.

- dinamică - subiectul a mers pe placa de presiune cu piciorul stâng. A fost obţinută o secvenţă în dinamică. Subiectul a repetat această mişcare cu piciorul drept. Au fost realizate cinci măsurători pe fiecare picior, în vederea obţinerii unor seturi de date fiabile şi comparabile.

Conform studiilor lui Naemi [6], pentru analize complete a mersului este recomandată folosirea unei plăci de presiune de trei metri lungime. Astfel, subiectul 
subject is walking or running on the pressure plate in several steps. Shorter walkways introduce more errors. In order to avoid errors and to obtain accurate data in the case of a $0.5 \mathrm{~m}$ platform, the subject was asked to make several trials before taking the measurements, until the recorded data was closer to his normal gait pattern [7-9].

\section{RESULTS AND DISCUSSIONS}

The static printout (Figure 1) gives the first information on the pressure distribution over the plantar area of the foot. For the investigated subject, the left foot is high arched, with a peak of pressure under the heel. The contact areas between foot and ground are on heel and on forepart only. For the right foot, the contact area in statics is higher compared with the left foot. This arrangement of pressures, from heel to forepart through middle part of the foot, indicates a balanced distribution that gives less pressure in the heel area. Figure 2 shows the distribution of pressures during all phases of rolling the feet on ground. It is obvious from these two sets of printouts that there is a difference between left and right foot both in statics and dynamics.

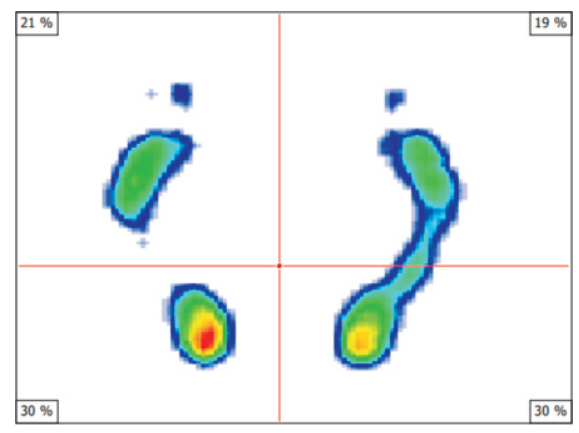

Figure 1. Static printout

Figura 1. Amprente în statică

For a normal gait pattern, the successive projections for centre of mass (line 1) should follow the foot axis (line 2). The foot axis is defined as a line connecting the centre of the heel and centre of the second metatarsal bone. For the left foot, the line of centre of mass (line 1 ) is near the foot axis (line 2). It can efectuează mai mulţi paşi pe placa de presiune, în diverse etape. Plăcile de presiune mai scurte introduc mai multe erori. Pentru a evita erorile şi a obţine date precise ale mersului pe o platformă de $0,5 \mathrm{~m}$, subiectul a fost rugat să facă mai multe teste înainte de efectuarea măsurătorilor, până când mersul înregistrat a fost adecvat modelului său normal de mers [7-9].

\section{REZULTATE ŞI DISCUTII}

Imaginea în statică (Figura 1) oferă primele informaţii cu privire la distribuirea presiunii pe suprafaţa plantară a piciorului. Pentru subiectul investigat, piciorul stâng este un picior scobit, cu presiune ridicată pe călcâi. Contactul dintre picior şi suprafaţa de sprijin este realizat doar pe călcâi şi pe partea anterioară. Pentru piciorul drept, suprafaţa de contact în statică este mai mare comparativ cu cea de pe piciorul stâng. Această distribuţie a presiunilor, de la călcâi, zona mediană a piciorului şi zona anterioară, indică o distribuţie echilibrată, care reduce presiunea în zona călcâiului. Figura 2 arată distribuţia presiunilor pe parcursul tuturor etapelor de efectuare a pasului. Este evidentă, în urma analizei acestor rezultate, diferenţa între piciorul stâng şi drept, atât în statică, cât şi în dinamică.
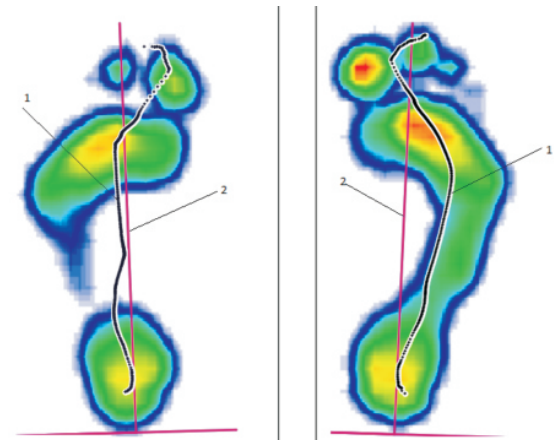

Figure 2. Dynamic printout

Figura 2. Amprente în dinamică

Pentru un model normal de mers, proiecţiile succesive ale centrului de greutate (linia 1) ar trebui să urmeze axa piciorului (linia 2). Axa piciorului este definită ca fiind linia care uneşte centrul călcâiului şi centrul celui de-al doilea metatarsian. Pentru piciorul stâng, linia de deplasare a centrului de greutate (linia 1) este aproape de axa piciorului (linia 2). Se poate 
be concluded that the balance of this foot is normal, even if it is a high arched foot. Concerning the right foot, the line of centre of mass is far away from the foot axis (line 2), that indicates a different rotation of ankle.

The gait cycle can be divided into three main stages: the first contact with the surface (impact), the stance stage when the entire foot is in contact with the ground, and the propulsion stage when the foot is pushing off the ground. Twenty phases of the gait cycle are presented for the left foot (Figure 3 ) and twenty phases for the right foot (Figure 4). For this case study, the left step time is $836 \mathrm{~ms}$ and the right step time is $722 \mathrm{~ms}$, both values being below the average step time of $900-990 \mathrm{~ms}$ reported in other studies.

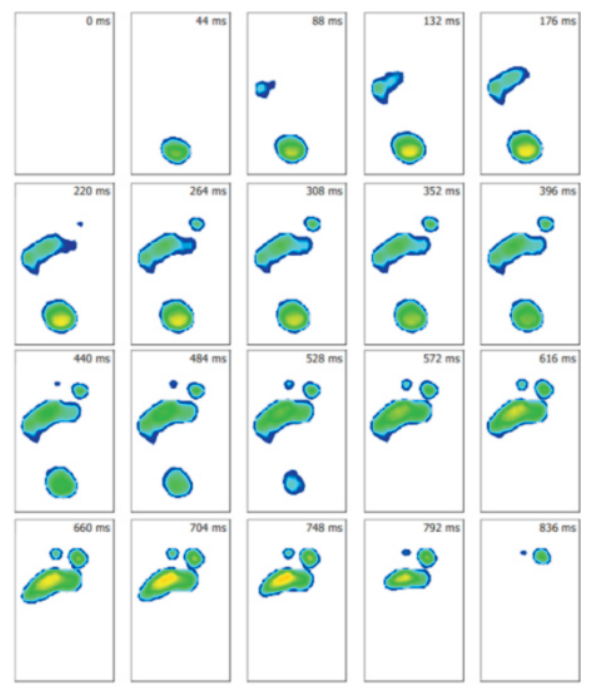

Figure 3. Left foot step time and related plantar print out during all stages of the gait cycle

Figura 3. Timpul de efectuare a unui pas pe piciorul stâng şi amprentele corespunzătoare fiecărei etape a fazei mersului

The left foot was defined as being high arched in statics, and it obviously differs from the right foot (Figure 1). These differences between left foot and right foot are also confirmed by measurements on walking. In Figure 3 it is shown that the left foot, which was defined as a high arched foot in orthostatic position, keeps the same characteristic in dynamics. As it could be observed from Figure 4, in the case of the right foot, the pressure is gradually distributed on the concluziona că echilibrul acestui picior este normal, chiar dacă este un picior puternic scobit. În ceea ce priveşte piciorul drept, linia de deplasare a centrului de greutate este îndepărtată de axa piciorului (linia 2), care indică o rotaţie diferită a gleznei.

Fazele mersului pot fi împărţite în trei etape principale: primul contact cu suprafaţa de sprijin (impact), etapa de sprijin, în care întregul picior este în contact cu solul şi faza de propulsie, atunci când piciorul se ridică de pe suprafaţa de sprijin. Douăzeci de faze ale ciclului de mers sunt prezentate pentru piciorul stâng (Figura 3) şi douăzeci de etape pentru piciorul drept (Figura 4). Pentru prezentul studiu, timpul de efectuare a unui pas cu piciorul stâng este de $836 \mathrm{~ms}$ şi timpul de efectuare a unui pas cu piciorul drept este de $722 \mathrm{~ms}$, ambele valori fiind sub durata medie de 900-990 ms raportată în alte studii.

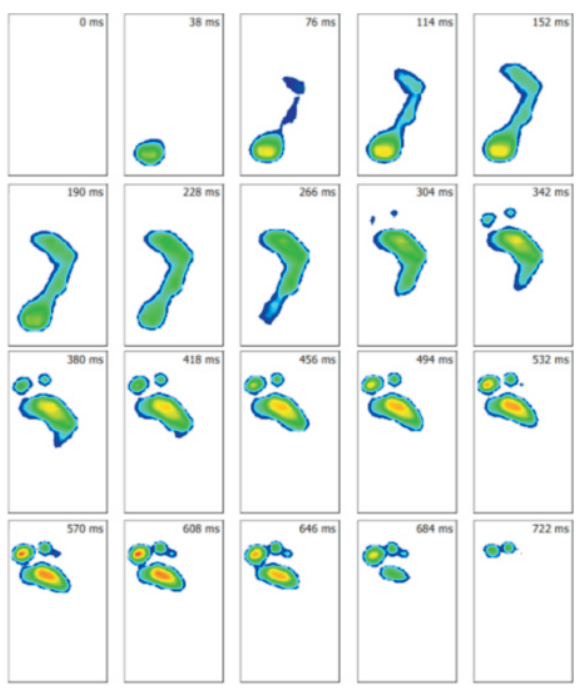

Figure 4. Right foot step time and related plantar print out during all stages of the gait cycle

Figura 4. Timpul de efectuare a unui pas pe piciorul drept şi amprentele corespunzătoare fiecărei etape a fazei mersului

Piciorul stâng a fost definit în statică ca fiind de tip picior scobit şi, evident, diferit de piciorul drept (Figura 1). Aceste diferenţe între piciorul stâng şi piciorul drept sunt, de asemenea, confirmate de măsurătorile în dinamică. În Figura 3 se arată că piciorul stâng, care a fost definit ca picior scobit, în poziţie de sprijin ortostatic, păstrează aceleaşi caracteristici în dinamică. După cum se poate observa din Figura 4, în cazul piciorului drept, presiunea este distribuită treptat pe 
lateral areas. This plantar pressure distribution over the stages of one step indicates an ankle rotation that is higher for the right foot compared with the left foot. Thus, the bones of the right foot are more stressed, and this could cause other irreversible changes on the gait pattern and body posture over the time.

Figure 5 presents the 3D views of the pressures as the foot areas comes in contact with the ground. In the first phase (impact), the main part of the pressure is on the heel; then in the second phase, body weight is still a bit on the heel, but on lateral areas and metatarsals too. Finally, in the third phase (propulsion), the body weight is all on metatarsal and toes. toată suprafaţa. Această distribuţie a presiunii plantare de-a lungul fazelor de mers indică o rotaţie a gleznei, care este mai mare în cazul piciorul drept, comparativ cu piciorul stâng. Astfel, oasele piciorului drept sunt mult mai solicitate, putând provoca modificări ireversibile de-a lungul timpului asupra modelului de mers şia posturii corpului.

În Figura 5 sunt prezentate vederi 3D ale presiunilor pe parcursul contactului dintre picior şi suprafaţa de sprijin. În prima fază (impact), cea mai mare presiune este pe călcâi, în cea de a doua fază, greutatea corpului este menţinută pe călcâi, dar şi pe zona laterală şi metatarsiene. În a treia etapă (propulsie), greutatea corporală este distribuită pe metatarsiene şi pe degete.

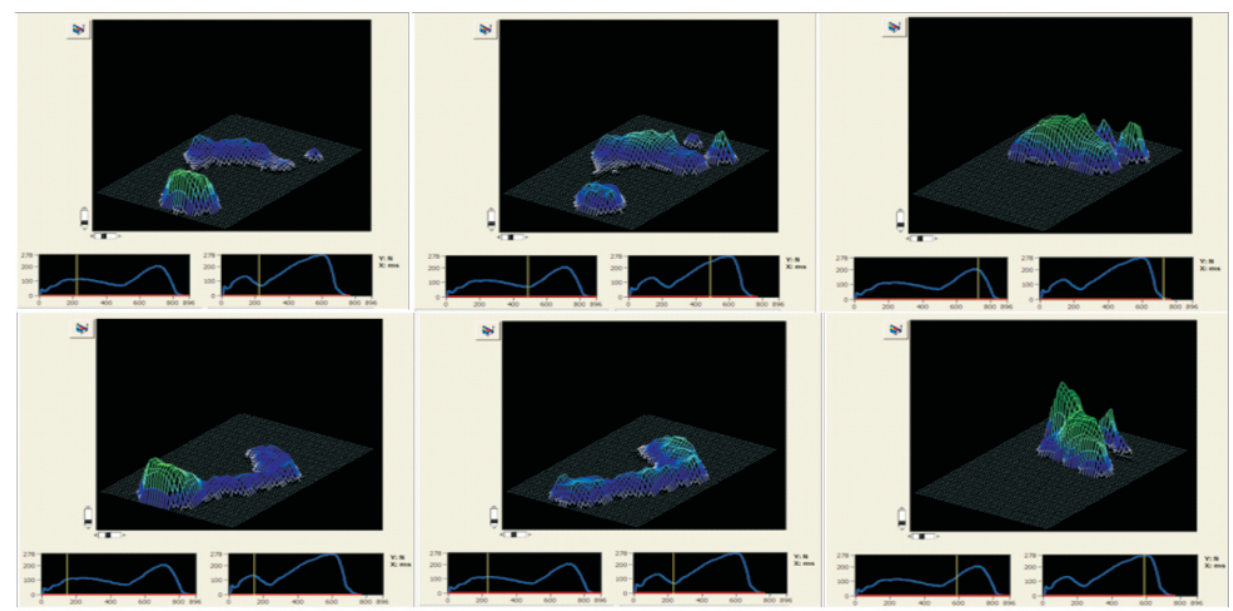

Figure 5. The 3D views of the pressures over the phases of gait (left foot: up; right foot: down) Figura 5. Vederi 3D ale presiunilor în timpul fazelor mersului (piciorul stâng: sus, piciorul drept: jos)

The Footscan software gives the pressure graphs depending on the foot areas (Figure 7). Therefore, the foot is divided into 10 areas (toe 1 , toe 2 to 5 , metatarsal 1 to 5 , medium foot, medial heel and lateral heel), each of them being differently coloured (Figure 6). The same legend of colours is kept for pressure graphs, in order to easily recognize how the pressure varies for each area of the foot.
Software-ul Footscan afişează graficele de presiune, în funcţie de zonele de contact ale piciorului (Figura 7). Prin urmare, piciorul este împărţit în 10 zone (degetul 1, degetele 2-5, metatarsienele 1-5, zona mediană, zona exterioară şi zona interioară a călcâiului), fiecare dintre aceste zone fiind colorate diferit (Figura 6). Aceeaşi legendă de culori este păstrată în graficele de presiune, în scopul recunoaşterii cu uşurinţă a modului în care variază presiunea pentru fiecare zonă a piciorului. 


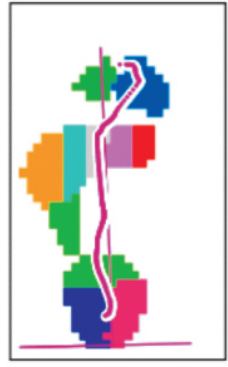

Left Foot

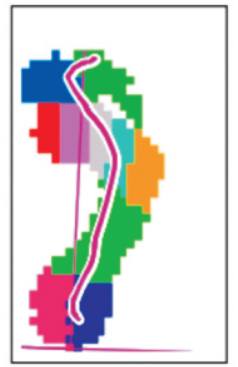

Right Foot

\begin{tabular}{c|c} 
Toe 1 & T1 \\
Toe 2 to 5 & T2-5 \\
Metatarsal 1 & M1 \\
Metatarsal 2 & M2 \\
\cline { 2 - 2 } Metatarsal 3 & M3 \\
Metatarsal 4 & M4 \\
\cline { 2 - 2 } Metatarsal 5 & M5 \\
Medium F oot & MF \\
Medial Heel & HM \\
Lateral Heel & HL
\end{tabular}

Figure 6. Foot areas and legend of codes and colours

Figura 6. Zonele piciorului şi legenda codurilor şi culorilor

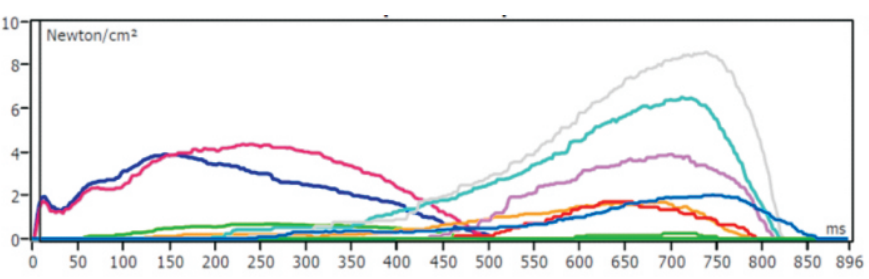

a) Left foot

a) Piciorul stâng

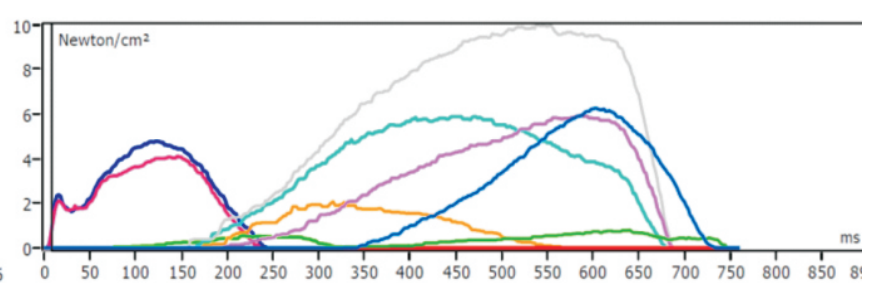

b) Right foot

b) Piciorul drept

Figure 7. Pressure graphs depending on the foot areas - left foot and right foot

Figura 7. Graficele presiunii în funcţie de zonele piciorului - picior stâng şi picior drept

Each pressure graph can be divided into 3 phases: heel contact, foot contact and push off. Two pressure peaks are visible on each graph: one during heel contact stage and one during pushing off stage (Figure 8). For a normal gait pattern, these two peaks have appropriate values. For the hereby case study a variation from normal situation is identified by observing higher pressures in propulsion stage compared with impact stage, in both feet.
Fiecare grafic de presiune poate fi împărţit în 3 faze: contact, sprijin pe toată suprafaţa piciorului şi propulsie. În fiecare grafic sunt vizibile două vârfuri de presiune: unul în faza de contact pe călcâi şi unul în faza de propulsie (Figura 8). Pentru un model normal de mers, aceste două vârfuri au valori corespunzătoare. Pentru prezentul studiu de caz este identificată o variaţie faţă de situaţia normală prin observarea unor presiuni ridicate pe ambele picioare în faza de propulsie comparativ cu faza de impact.

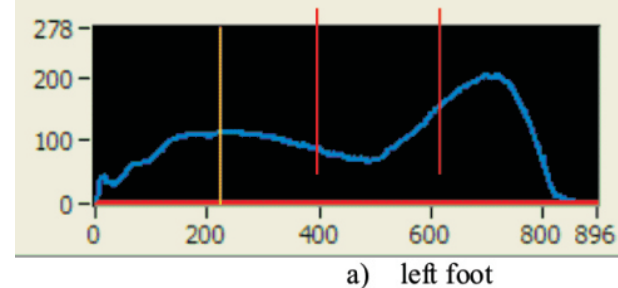

a) piciorul stâng

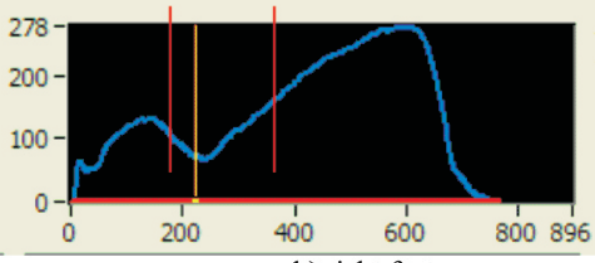

b) right foot

b) piciorul drept

Figure 8 . The three phases of gait - impact, stance and propulsion (separated by red lines)

Figura 8. Cele trei faze ale mersului - impact, sprijin şi propulsie (separate de liniile roşii)

In order to complete the view of the movement, a Gantt graph (Figure 9) that shows different parameters
În vederea ilustrării mişcării a fost realizat un grafic Gantt (Figura 9), care arată diferiţi parametri şi 
and their interactions is made. This diagram illustrates the arrangements of the mean values of pressures over the time in five areas: the 1st toe, the 1st, 3rd and 5th metatarsal bones, and under the lateral heel. The values given by Footscan software in five different tables were analysed and some values have been excluded because they did not follow the normal distribution. interacţiunile dintre aceştia. Această diagramă ilustrează valorile medii ale presiunilor în funcţie de timp, pe cinci zone ale piciorului, degetul 1, metatarsienele 1, 3 şi 5, şi zona exterioară a călcâiului. $\mathrm{Au}$ fost analizate valorile obţinute prin intermediul aplicaţiei Footscan şi încadrate în cinci tabele diferite, unele dintre valori fiind excluse, deoarece acestea nu urmăreau o distribuţie normală.

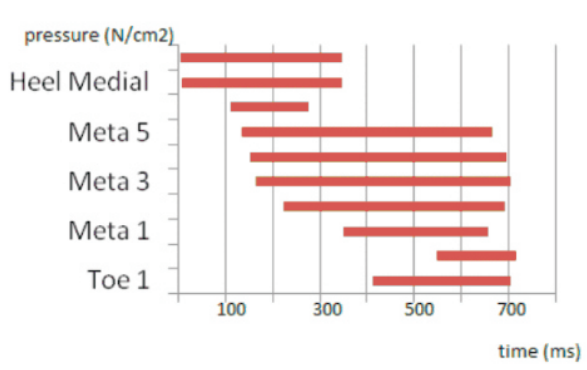

a) left foot

a) piciorul stâng

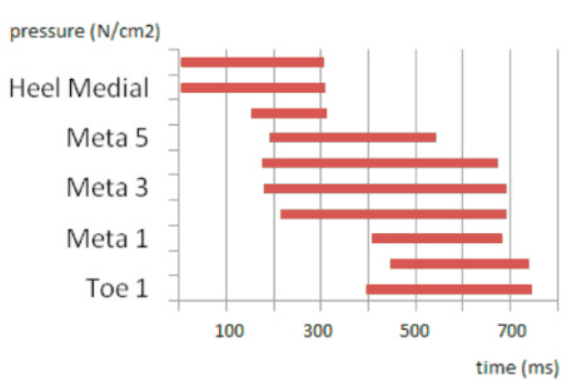

b) right foot

b) piciorul drept

Figure 9. Gantt graph for left and right foot (time in ms)

Figura 9. Diagrame Gantt pentru piciorul stâng şi piciorul drept (timp în ms)

The Gantt graphs indicate differences between left foot and right foot. The left foot is moving faster and the arrangement of bars is more compact compared with the one for the right foot. One can see that in the case of the right foot the first toe is under stress for a longer time compared with the time than for the left foot. Also, it is shown that heel is working for almost half the time of a gait. Table 1 presents the minimum and maximum values of pressures on left and right foot. The mean and standard deviation have been calculated. The bar chart from Figure 10 presents the pressure values for left and right foot.
Diagramele Gantt indică diferenţe între piciorul stâng şi piciorul drept. Piciorul stâng se mişcă mai repede, iar modul de aranjare al barelor este mai compact în comparaţie cu cele de la piciorul drept. Se poate vedea că, în cazul piciorului drept, primul deget de la picior este solicitat pentru o perioadă mai lungă în comparaţie cu degetul mare de la piciorul stâng. De asemenea, se observă faptul că, în aproape jumătate din timpul necesar efectuării unui pas, călcâiul este solicitat. În Tabelul 1 sunt prezentate valorile minime şi maxime ale presiunilor pentru piciorul drept şi pentru piciorul stâng. Au fost calculate media şi abaterea medie pătratică. În diagrama cu bare din Figura 10 sunt prezentate valorile presiunilor pentru piciorul stâng şi drept.

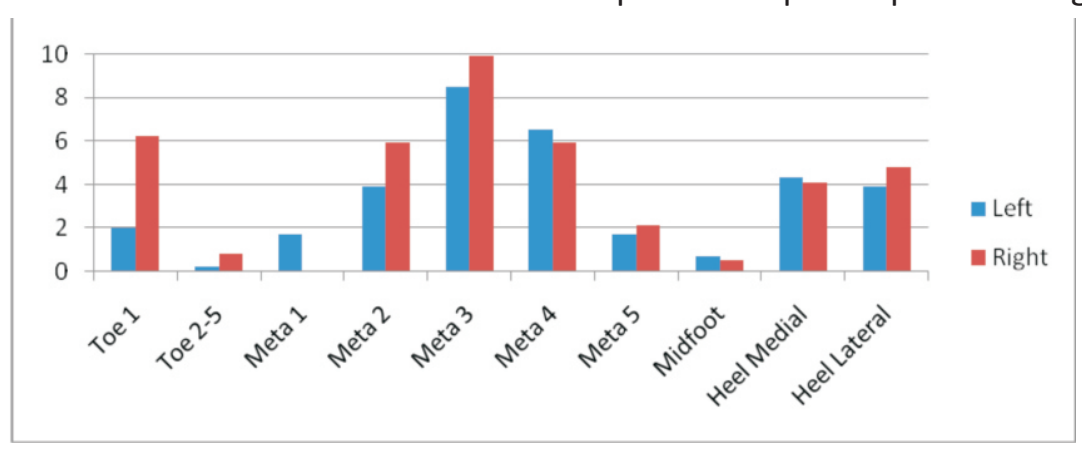

Figure 10. Maximum pressures on various areas of the foot (left and right)

Figura 10. Presiuni maxime în diferite zone ale piciorului (stâng şi drept) 
For the right foot, the pressures are higher under $1^{\text {st }}$ toe, $2^{\text {nd }}$ and $3^{\text {rd }}$ metatarsal areas, compared with the left foot. For both feet, the highest pressures are registered under $3^{\text {rd }}$ and $4^{\text {th }}$ metatarsal bones, suggesting that these areas have a higher risk of developing bone deformations or ulcerations.
Pentru piciorul drept, în comparaţie cu piciorul stâng, presiunile sunt mai mari sub degetul mare, metatarsienele 2 şi 3. Pentru ambele picioare, cele mai mari presiuni sunt înregistrate în zona metatarsienelor 3 şi 4, ceea ce sugerează ca aceste zone prezintă un risc mai mare de dezvoltare a deformărilor osoase sau a ulceraţiilor.

Table 1: Comparison of max pressures on different areas of foot and Student Test on the means

Tabelul 1: Comparaţii ale presiunilor maxime pe diferite zone ale piciorului şi testul Student al mediilor

\begin{tabular}{|c|c|c|c|c|c|c|c|c|c|}
\hline \multicolumn{5}{|c|}{$\begin{array}{l}\text { Pressure }\left(\mathrm{N} / \mathrm{cm}^{2}\right) \text { - Left Foot } \\
\text { Presiune }\left(\mathrm{N} / \mathrm{cm}^{2}\right) \text { - Piciorul stâng }\end{array}$} & \multicolumn{5}{|c|}{$\begin{array}{l}\text { Pressure }\left(\mathrm{N} / \mathrm{cm}^{2}\right) \text { - Right Foot } \\
\text { Presiune }\left(\mathrm{N} / \mathrm{cm}^{2}\right) \text { - Piciorul drept }\end{array}$} \\
\hline $\begin{array}{l}\text { Area } \\
\text { Zonă }\end{array}$ & $\begin{array}{l}\text { Min. } \\
\text { Value } \\
\text { Valoare } \\
\text { minimă }\end{array}$ & $\begin{array}{l}\text { Max. } \\
\text { Value } \\
\text { Valoare } \\
\text { maximă }\end{array}$ & $\begin{array}{l}\text { Mean } \\
\text { Medie }\end{array}$ & $\begin{array}{l}\text { SD } \\
\text { Abatere } \\
\text { standard }\end{array}$ & $\begin{array}{l}\text { Area } \\
\text { Zonă }\end{array}$ & $\begin{array}{l}\text { Min. } \\
\text { Value } \\
\text { Valoare } \\
\text { minimă }\end{array}$ & $\begin{array}{l}\text { Max. } \\
\text { Value } \\
\text { Valoare } \\
\text { maximă }\end{array}$ & $\begin{array}{l}\text { Mean } \\
\text { Medie }\end{array}$ & $\begin{array}{l}\text { SD } \\
\text { Abatere } \\
\text { standard }\end{array}$ \\
\hline $\begin{array}{l}\text { Toe } 1 \\
\text { Deget } 1\end{array}$ & 0.2 & 6.6 & 2.8 & 2.3 & $\begin{array}{l}\text { Toe } 1 \\
\text { Deget } 1\end{array}$ & 4.6 & 20.2 & 8.4 & 6.7 \\
\hline $\begin{array}{l}\text { Toe } 2-5 \\
\text { Degete 2-5 }\end{array}$ & 0.1 & 0.7 & 0.4 & 0.3 & $\begin{array}{l}\text { Toe } 2-5 \\
\text { Degete 2-5 }\end{array}$ & 0.2 & 6.8 & 1.9 & 2.8 \\
\hline $\begin{array}{l}\text { Metatarsal } 1 \\
\text { Metatarsian } 1\end{array}$ & 0.5 & 1.8 & 1.3 & 0.6 & $\begin{array}{l}\text { Metatarsal } 1 \\
\text { Metatarsian } 1\end{array}$ & 0.2 & 2.1 & 1.1 & 0.8 \\
\hline $\begin{array}{l}\text { Metatarsal } 2 \\
\text { Metatarsian } 2\end{array}$ & 3.9 & 11.6 & 6.3 & 3.1 & $\begin{array}{l}\text { Metatarsal } 2 \\
\text { Metatarsian } 2\end{array}$ & 3.5 & 11.9 & 6.3 & 3.2 \\
\hline $\begin{array}{l}\text { Metatarsal } 3 \\
\text { Metatarsian } 3\end{array}$ & 10.2 & 16.2 & 12.2 & 2.4 & $\begin{array}{l}\text { Metatarsal } 3 \\
\text { Metatarsian } 3\end{array}$ & 6.3 & 18.5 & 9.6 & 5.1 \\
\hline $\begin{array}{l}\text { Metatarsal } 4 \\
\text { Metatarsian } 4\end{array}$ & 6.6 & 11.2 & 8.9 & 2.0 & $\begin{array}{l}\text { Metatarsal } 4 \\
\text { Metatarsian } 4\end{array}$ & 3.8 & 8.8 & 5.5 & 2.0 \\
\hline $\begin{array}{l}\text { Metatarsal } 5 \\
\text { Metatarsian } 5\end{array}$ & 1.9 & 6.3 & 3.5 & 1.7 & $\begin{array}{l}\text { Metatarsal } 5 \\
\text { Metatarsian } 5\end{array}$ & 0.5 & 3.3 & 1.5 & 1.1 \\
\hline $\begin{array}{l}\text { Midfoot } \\
\text { Zona mediană }\end{array}$ & 0.2 & 0.4 & 0.3 & 0.1 & $\begin{array}{l}\text { Midfoot } \\
\text { Zona mediană }\end{array}$ & 0.1 & 1.1 & 0.5 & 0.4 \\
\hline $\begin{array}{l}\text { Heel Medial } \\
\text { Exteriorul } \\
\text { călcâiului }\end{array}$ & 5.4 & 6.6 & 6.0 & 0.5 & $\begin{array}{l}\text { Heel Medial } \\
\text { Exteriorul } \\
\text { călcâiului }\end{array}$ & 4.6 & 12.8 & 6.7 & 3.4 \\
\hline $\begin{array}{l}\text { Heel Lateral } \\
\text { Interiorul } \\
\text { călcâiului }\end{array}$ & 3.6 & 10.3 & 5.5 & 2.8 & $\begin{array}{l}\text { Heel Lateral } \\
\text { Interiorul } \\
\text { călcâiului }\end{array}$ & 3.8 & 10.1 & 6.4 & 2.4 \\
\hline $\begin{array}{l}\text { Student Test } \\
\text { (mean) } \\
\text { Testul Student } \\
\text { (medii) }\end{array}$ & $p=0.9>c$ & & & & & & & & \\
\hline
\end{tabular}

Based on the human body symmetry, the initial hypothesis is that there are no significant differences between left and right foot. To test this hypothesis, a Student test is conducted for a preset probabilistic limit of $p=0.05$. If the result of the Student test is inferior to $p$,
În baza simetriei corpului uman, se presupune că nu există diferenţe semnificative între piciorul stâng şi piciorul drept, reprezentând ipoteza iniţială. Pentru testarea acestei ipoteze, a fost aplicat un test Student, pentru o limită prestabilită $p=0,05$. Dacă rezultatul 
then the hypothesis is rejected. For the hereby case study, the calculated value for Student test is 0.9 , that is higher than $p=0.05$. Thus, the initial hypothesis is accepted and there are no significant differences between left and right foot. Even if the investigated subject has visible differences in terms of pressure distribution between left and right foot in statics, the analysis of values in dynamics demonstrates that there are no significant statistical differences in dynamics.

\section{CONCLUSIONS}

The foot is divided into anatomical areas in order to calculate plantar pressure parameters. Generically, the mean, the peak, and the time-pressure integrals of plantar pressure are used $[9,10]$. When these parameters have high values in specific areas of the foot, they can be seen as indicators of potential injuries [11]. For example, in western population plantar pressures concentrate mainly under the $2^{\text {nd }}$ and $3^{\text {rd }}$ metatarsal bones and under the heel. This could cause serious efforts while walking, and it also gives an unpleasant feeling of discomfort [10,12].

The paper presents a methodology for analysing the footprints of one subject that has visible differences on pressure distribution in statics. For orthopaedists, it could be a very good example of establishing the typology of the foot in order to suggest special devices to be introduced inside the shoe or customized soles and insoles. Using RSScan pressure plate and Footscan software a very fine observation of the foot and the foot pressure repartition is made. By comparing the maximum pressures, the highest are registered under $3^{\text {rd }}$ and $4^{\text {th }}$ metatarsal bones, suggesting that these areas have a higher risk of developing injures and structural or functional bone modifications. A Student test is conducted to compare the pressures between left and right foot. The result of this test is that there are no significant differences between the pressures of the two feet, and therefore no need to separately design the bottom components. An analysis of gait time was made, the result being a normal distribution on each testului Student este inferior lui $p$, atunci ipoteza este respinsă. Pentru prezentul studiul de caz, valoarea calculată pentru testul Student este 0,9, fiind mai mare decât $p=0,05$. Astfel, ipoteza iniţială este acceptată şi nu există diferenţe semnificative între piciorul stâng şi piciorul drept. Chiar dacă subiectul investigat are diferenţe vizibile privind distribuţia presiunilor între piciorul stâng şi piciorul drept în statică, analiza valorilor în dinamică demonstrează că nu există diferenţe semnificative din punct de vedere statistic în dinamică.

\section{CONCLUZII}

În vederea calculării parametrilor de presiune plantară, piciorul este împărţit în zone anatomice. Sunt folosite la modul generic media, vârfurile de presiune şi integralele timp-presiune [9, 10]. Atunci când aceşti parametri au valori mari în anumite zone ale piciorului, pot fi interpretaţi ca indicatori ai unor potenţiale răni [11]. De exemplu, populaţia occidentală prezintă presiuni plantare ridicate mai ales în zona oaselor metatarsienelor 2 şi 3 şi sub călcâi. Aceasta ar putea cauza solicitări serioase în timpul mersului şi, de asemenea, oferă un sentiment neplăcut de disconfort [10,12].

Lucrarea prezintă o metodologie pentru analiza amprentelor unui subiect care are diferenţe vizibile privind distribuţia presiunii în statică. Pentru ortopezi, ar putea fi un foarte bun exemplu de stabilire a tipologiei piciorului, în vederea sugerării dispozitivelor speciale pentru a fi introduse în interiorul încălţămintei sau a branţurilor şi tălpilor personalizate. Folosind placa de presiune RSScan şi software-ul Footscan se observă cu atenţie piciorul şi repartiţia presiunilor la nivelul acestuia. Prin compararea presiunilor maxime, cea mai mare este înregistrată în zona oaselor metatarsiene 3 şi 4, ceea ce sugerează că aceste zone prezintă un risc ridicat de dezvoltare a leziunilor şi a modificărilor osoase structurale sau funcţionale. A fost efectuat un test Student pentru compararea presiunilor între piciorul stâng şi piciorul drept. Rezultatul acestui test a demonstrat că nu există diferenţe semnificative între presiunile celor două picioare, nefiind astfel necesară proiectarea unor componente inferioare diferite ale încălţămintei. A fost realizată o analiză a timpului de mers, rezultatul fiind o distribuţie normală pe fiecare zonă a piciorului. Prin 
area of the foot. By conducting five tests, all errors have been eliminated; and then the left foot has been demonstrated to be a high arched foot. efectuarea a cinci teste, orice eroare a fost eliminată, iar apoi a fost demonstrat faptul că piciorul stâng este un picior scobit.

\section{REFERENCES}

1. Orlin, M.N., McPoil, T.G., Plantar pressure assessment, Physical Therapy, 2000, 80, 4, 399-409.

2. Rai, D.V., Aggarwal, L.M., The study of plantar pressure distribution in normal and pathological foot, Pol J Med Phys Eng, 2006, 12, 25-34.

3. Shorten, M., Plantar pressure distribution and footwear design, Footwear Sci, 2009, 1, 88-90.

4. Tsung, B.Y.S., Zhang, M., Mak, A.F.T., Wong M.W.N., Effectiveness of insoles on plantar pressure redistribution, $J$ Rehabil Res Dev, 2004, 41, 6, 767-774.

5. Keijsers, N.L.W., Stolwijk, N.M., Pataky, T.C., Linear dependence of peak, mean, and pressure-time integral values in plantar pressure images, Gait Posture, 2010, 31, 1, 140-142, available on http://www.sciencedirect.com/science/

6. Naemi, R., Larose Chevalier, T., Chockalingam, N., Healy, A., The effect of the use of a walkway and the choice of the foot on plantar pressure assessment when using pressure platforms, The Foot, 2012, 22, 2, 100-104.

7. Vasilescu, A.M., Pantazi, M., Micu, A.C., Ground reaction force analysis in normal gait using footwear with various heel heights on different surfaces, The $4^{\text {th }}$ International Conference on Advanced Materials and Systems, ICAMS 2012, 205-210.

8. Keijsers, N.L.W., Stolwijk, N.M., Nienhuis, B., Duysens, J., A new method to normalize plantar pressure measurements for foot size and foot progression angle, J Biom, 2009, 42, 1, 87-90, available on http://www.sciencedirect.com/

9. Petcu, D., Karavana, H.A., Berijan, G., Change of the Foot Morphology depending on the Plantar Surface 3D Capture Method, Revista de Pielarie Incaltaminte (Leather and Footwear Journal), 2010, 10, 2, 5-18.

10. Keijsers, N.L.W., Stolwijk, N.M., Louwerens, J.W.K., Duysens, J., Classification of forefoot pain based on plantar pressure measurements, Clin Biomech, 2013, 28, 3, 350-356, available on http://www.sciencedirect.com/

11. Naemi, R. Alonso, A.P., Chockalingam, N., Larose Chevalier, T., Effects of walkway inclusion in pressure platform assessment, Footwear Sci, 2009, 1, 23-24.

12. D'Août, K., Pataki, T.C., De Clercq, D., Aerts, P., The effects of habitual footwear use: foot shape and function in native barefoot walkers, Footwear Sci, 2009, 1, 2, 103-105. 